\title{
DETERMINATION OF AMINO ACID COMPOSITION OF BROCCOLI CABBAGE PROTEIN
}

\author{
Svitlana Belinska \\ Department of commodity science, safety and quality management \\ Kyiv National University of Trade and Economics \\ 19 Kioto str., Kyiv, Ukraine, 02156 \\ prodt@knteu.kiev.ua \\ Nataliia Kamienieva \\ Department of commodity science, safety and quality management \\ Kyiv National University of Trade and Economics \\ 19 Kioto str., Kyiv, Ukraine, 02156 \\ nataliakameneva32@gmail.com \\ Stanislava Levytska \\ Department of commodity science, safety and quality management \\ Kyiv National University of Trade and Economics \\ 19 Kioto str., Kyiv, Ukraine, 02156 \\ levitskaya_stan@ukr.net \\ Sergiy Rogalskiy \\ Department of Crop Production \\ Uman National University of Horticulture \\ 1 Instytutska str., Uman, Ukraine, 20305 \\ shark32008@yandex.ua
}

\footnotetext{
Abstract

A wide range of fresh fruits and vegetables grown in different geographical areas and represented in international trade networks has changed the consumers' approaches to their choice. The determining criterion of choice is the biological value of plant raw materials, is determined by the content of amino acids, vitamins, mineral elements, $\beta$-carotene, which play a significant role in ensuring the functioning of the human body. The chemical composition of fruits and vegetables is highly variable and depends on the type, variety of vegetables, agro climatic conditions of their cultivation, storage characteristics and requires study.

The study of the amino acid composition and biological value of the protein of the broccoli varieties of French and Dutch selections, which are regionalized in Ukraine, will determine the most promising varieties in order to provide the population with full-fledged proteins of plant origin.

The amino acid composition of the protein of the broccoli Parthenon, Belstar F1, Quinta F1, Monaco F1 is regionalized and suitable for cultivation in different geographical regions of Ukraine. Calculation of the amino acidic score and biological value of the broccoli cabbage protein on which the varieties were ranked.

8 indispensable and 8 dispensable amino acids are identified and quantified. It is found that the greatest content of indispensable amino acids is characteristic for cabbage varieties Parthenon (41.95 mg/100 mg protein) and Belstar F1 (42.26 mg/100 mg protein). All the investigated varieties of broccoli cabbage don't differ significantly in this indicator.

A high content of glutamic acid (from 16.27 to $18.43 \mathrm{mg} / 100 \mathrm{mg}$ protein), aspartic acid (from 9.54 to $10.56 \mathrm{mg} / 100 \mathrm{mg}$ protein), arginine (from 6.02 to $6.90 \mathrm{mg}$ ) is found in the dispensable amino acids in broccoli cabbage varieties $/ 100 \mathrm{mg}$ ).

The calculated amino acid scores show that the broccoli cabbage protein is a valuable source of isoleucine, methionine, phenylalanine and tryptophan. The score of methionine, tryptophan and isoleucine ranges from $165.1 \%$ to $183.1 \%$; from 121.0 to $156.0 \%$ and from 115.3 to $127.8 \%$ respectively.

Species of broccoli cabbage are identified, the protein of which has the highest biological value. The performed calculations confirm that the highest biological value is possessed by the broccoli cabbage protein of Quinta F1 variety (64.2\%). This variety is the most balanced in its amino acid composition compared to other varieties. The biological value of the protein of the varieties of Monaco F1, the Parthenon is different and amounted to $63.2 \%$ and $63.1 \%$, respectively. The lowest biological value is found for the protein Belstar F1 $-60.5 \%$.
} 
The research results of the amino acid composition and biological value of the broccoli cabbage protein of varieties bred and grown in different countries will contribute to the expansion of the scientific database on the effect of climatic growing conditions on the biological value of the broccoli cabbage protein.

The obtained results can also be useful for specialists in the agrarian sector and the fruit and vegetable industry.

Keywords: broccoli cabbage, amino acid composition, biological value, protein quality evaluation.

\section{Introduction}

Proteins of vegetable and animal origin, which differ in amino acid composition, play an important role in the life of the human body. Of the 20 amino acids, 12 indispensable can be synthesized by the body and 8 dispensable ones must come with products. In the structure of world production of protein, potentially suitable for human nutrition, part of the vegetable belongs to $81 \%$. The main sources of its supply are cereals, legumes, oilseeds, root- and tuber crops, vegetables, melons and nuts [1].

The research results of the protein component of various types of fresh and processed fruits and vegetables show that the biological value of the protein of fruit and vegetable products depends on the species composition [2, 3], varietal features [4] and pre-treatment methods [5, 6].

The biological value of vegetable protein is lower in comparison with the animal. From vegetable cultures, only the proteins of potato and white cabbage are close to animals by the content of indispensable amino acids [7].

It is known that to provide the body with a high-quality protein, vegetables do not play a decisive role for their low content in plant raw materials and insignificant consumption volumes. Since the protein of plant material is in dense cell membranes and difficult to digest enzymes, this reduces their digestibility, which, depending on the type of vegetables is in the range of $70-80 \%$.

In Ukraine, the demand for broccoli cabbage [8] is increasing year by year, which in its chemical composition takes a leading place not only among varieties of cabbage, but also among other vegetable crops. Taking into account varietal features, cabbage contains vitamin $\mathrm{C}$ from 100 to $180 \mathrm{mg} / 100 \mathrm{~g}$, is a source of vitamin B1, B2, K, PP and folic acid [9]. Its biological value is also determined by amino acids, mineral elements, chlorophyll, $\beta$-carotene, glucosinolates. Analysis of scientific sources confirms that the consumption of broccoli cabbage provides a daily requirement of the body in proteins by $5-6 \%$, and their digestibility is $80 \%$ [7].

The composition of the broccoli protein includes anti-sclerotic substances (lysine, isoleucine, choline, methionine), preventing the accumulation of cholesterol in the body and preventing its premature aging.

It should be noted that broccoli is a seasonal vegetable, so the possibility of its consumption in fresh form is limited by the shelf life. The most appropriate method of preservation, in which minimal changes in consumer properties occur, is freezing. The authors of the work carried out a number of studies to determine the content of biologically active substances in broccoli in cabbage, in particular ascorbic acid, chlorophyll, glucosinolates, $\beta$-carotene in fresh raw materials and after pre-treatment technological stages before freezing: blanching and soaking in a solution of common salt. The research results confirm that broccoli is a valuable vegetable crop, the varieties of which differ somewhat in the content of the above substances, and its consumption should not be limited to the harvest season.

The study of the protein component, in particular the amino acid composition and the biological value of the protein of varieties of broccoli cabbage in the varietal profile, was not carried out in Ukraine.

The aim of research is studying the amino acid composition and biological value of the protein of the broccoli varieties of French and Dutch breeding sprouted in Ukraine. This will determine the most promising varieties of broccoli cabbage in order to provide the population with highgrade vegetable proteins. The research results of the amino acid composition and biological value 
of the broccoli cabbage protein of varieties bred and grown in different countries will contribute to expanding the scientific database on the effect of climatic growing conditions on the biological value of the broccoli cabbage protein.

\section{Materials and methods}

The object of research is the protein of the varieties of broccoli Parthenon (the method of creation is a hybrid, the French selection) (Fig. 1), Monaco F1 (the method of creation is a hybrid, Dutch selection) (Fig. 2), Belstar F1 (hybrid method, Dutch selection (Fig. 3), Quinta F1 (hybrid method, Dutch selection) (Fig. 4), grown in the same agroclimatic conditions on the fields of LLC "ARTI" (Ukraine, Kharkiv region) and included in the State Register of Plant Varieties, suitable for distribution in Ukraine for 2016 [10]. Varieties differ morphological (size, shape, color of the inflorescence) and economic and botanical features (yield, vegetation period) and are recognized by farmers as the most promising for growing in the forest-steppe zone of Ukraine.

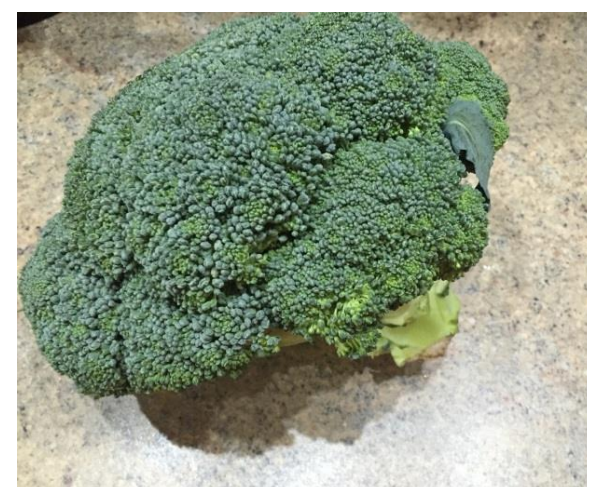

Fig. 1. Parthenon broccoli cabbage

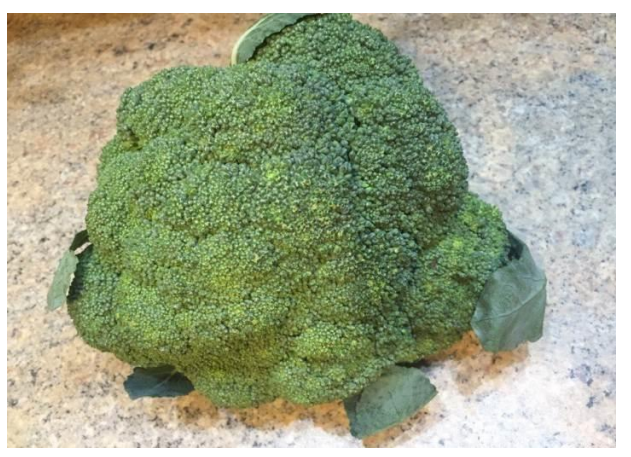

Fig. 2. Monaco F1 broccoli cabbage

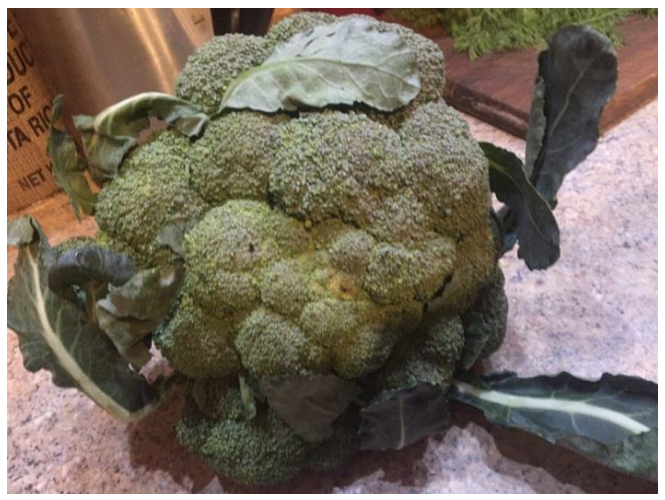

Fig.3. Quinta F1 broccoli cabbage 


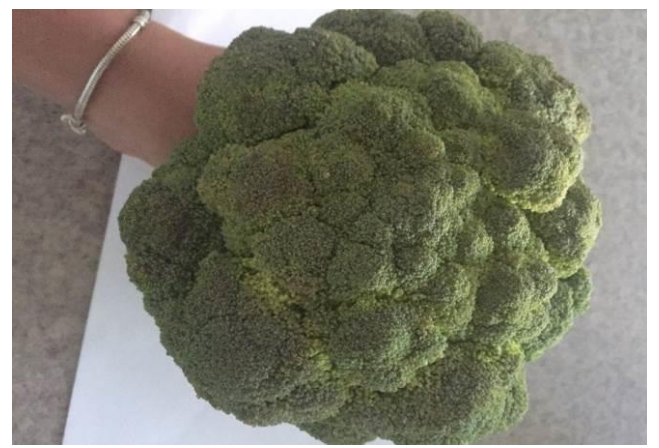

Fig.4. Belstar F1 broccoli cabbage

The raw material was previously dried to constant weight and ground. $0.3 \mathrm{~g}$ sample was placed in a test tube with ground glass stopper, $10 \mathrm{~cm}^{3}$ of distilled water and $10 \mathrm{~cm}^{3}$ of concentrated hydrochloric acid were poured. Test tube was tightly sealed and placed in an oven at $130{ }^{\circ} \mathrm{C}$ for 8 hours. The resulting hydrolyzate was filtered through a cotton filter and washed with 3 volumes of distilled water. The resulting solution was transferred to a porcelain dish and evaporated on an electric plate to a volume of $0.5 \ldots 1.0 \mathrm{ml}$. The resulting sample was diluted with distilled water and filtered through a paper filter into a $50 \mathrm{ml}$ test tube and the filter was rinsed until the tube was filled to $35-40 \mathrm{ml}$. If the $\mathrm{pH}$ of the obtained sample was different from $2.2 \pm 0.02$ units, then it was corrected with $0.1 \mathrm{~N}$ solutions of $\mathrm{HCl}$ or $\mathrm{NaOH}$ to the required value.

The research was conducted on the following indicators:

- Amino acid content was determined by ion-exchange column chromatography on an automatic amino acid analyzer AAA 339M ("Microtechna", Czech Republic) [11] (Fig. 5). From the prepared sample $1 \mathrm{ml}$ was taken and $1 \mathrm{ml}$ of a buffer solution with $\mathrm{pH}=2.2$ were added. The resulting sample was passed through a membrane filter with a pore diameter of $0.45 \mu \mathrm{m} .50 \mu \mathrm{l}$ of the purified sample was collected and introduced into the chromatographic ion exchange column of the AAA 339 analyzer. The analysis was then automatically carried out by a program with duration of 115 minutes. After the analysis, obtained chromatograms were deciphered and the peak area of each amino acid was calculated by the external standard method. Tryptophan during acid hydrolysis of the protein almost completely disintegrates, therefore for its determination a separate analysis was carried out by alkaline hydrolysis of $2 \mathrm{n} \mathrm{NaOH}$ at $100^{\circ} \mathrm{C}, 16 \ldots 18$ hours in the presence of $5 \%$ tin chloride. The hydrolyzate, after appropriate neutralization with a mixture of citric and hydrochloric acid, was immediately (for prevention of drag formation) analyzed on an amino acid analyzer.

- To calculate the quantitative composition of amino acids on the chromatogram, the peak height of each amino acid was determined. The number of micro moles of each amino acid $\left(\mathrm{X}_{1}\right)$ in the test solution was calculated by the formula:

$$
\mathrm{x}_{1}=\frac{\mathrm{S}_{1}}{\mathrm{~S}_{0}}
$$

where $S_{1}$ is the height of the amino acid peak in the test sample; $S_{0}$ is the height of the peak of the same amino acid in the control solution (the standard mixture of amino acids: valine, isoleucine, leucine, methionine, cystine, threonine, phenylalanine, tyrosine, tryptophan, arginine, glutamic acid, lysine, serine, glycine, alanine and proline) corresponds to $1 \mu \mathrm{mol}$ of the amount of each amino acid.

The amount (mg) was obtained by multiplying the amount of micromoles of the amino acid by its corresponding molecular weight. The qualitative composition of the mixture of amino acids was determined by comparing the chromatogram of the control and the studied mixture of amino acids [12]. 
- Amino acid score (AS, \%) was calculated by determining the percentage of indispensable amino acid in the test protein relative to the content of a similar amino acid in a hypothetical "ideal" protein. Amino acid with a low index is limiting and indicates the degree of use of this protein. The basis for the analytical calculation of the value of protein is the hypothesis of the dominant effect of the first limiting amino acid.

- The coefficient of ambiguity of the amino acidic score (AAS, \%) was determined as the average excess amino acid quantity of the fastest indispensable amino acids in comparison with the lowest level of the indispensable amino acid. AAS indicates the percentage of indispensable amino acids that are not used for plastic needs.

- Biological value (BV, \%) was determined on the basis of the calculated AAS as the difference between the potentially possible $(100 \%)$ and actually established fraction of the use of indispensable amino acids for plastic needs. This indicator was determined from the total content of indispensable amino acids, which should be at least $40 \mathrm{~g}$ per $100 \mathrm{~g}$ of protein.

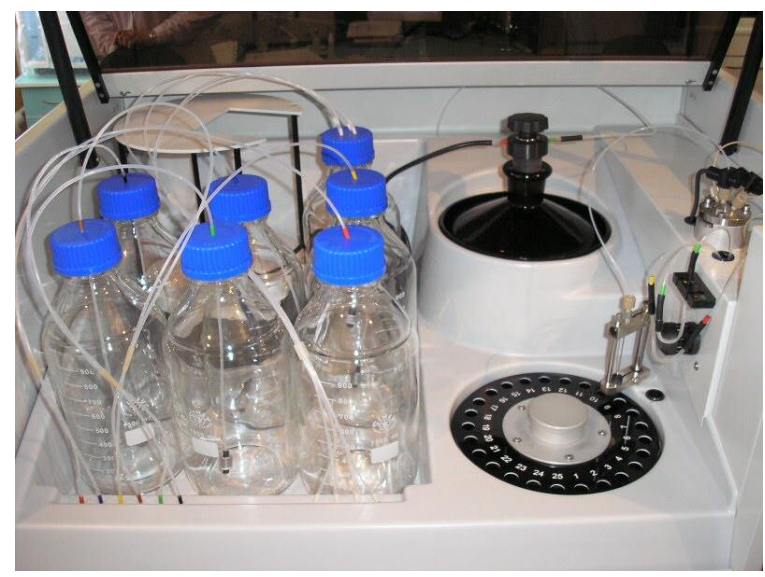

Fig. 5. Amino acid analyzer AAA 339M

\section{Research results}

Investigations of the amino acid composition of the broccoli cabbage protein have made it possible to identify and quantify 8 indispensable amino acids and 10 dispensable amino acids (Table 1).

When determining the amino acid composition of the protein, it was found that the greatest content of indispensable and dispensable amino acids is characteristic of the Parthenon variety (41.95 and $57.13 \mathrm{mg} / 100 \mathrm{mg}$ of protein, respectively) and Belstar F1 (42.26 and $57.91 \mathrm{mg} / 100 \mathrm{mg}$, respectively). However, it should be noted that the investigated varieties of broccoli cabbage did not differ significantly in this indicator.

A qualitative composition of indispensable amino acids is found to confirm their importance for the functioning of the human body. It is known that when there is a lack of leucine in the human body, there is a disturbance in the process of hematopoiesis, a decrease in the number of red blood cells and a hemoglobin level in the blood, lysine - the body weight decreases sharply, and changes occur in the kidneys and thyroid gland. [13] Tryptophan is responsible for the synthesis of hemoglobin, regulates the function of the endocrine system. [13].

A high content of glutamic acid (from 16.27 to $18.43 \mathrm{mg} / 100 \mathrm{mg}$ of protein), aspartic acid (from $9.54 \ldots 10.56 \mathrm{mg} / 100 \mathrm{mg}$ of protein), arginine (from $6.02 \ldots 6.90 \mathrm{mg} / 100 \mathrm{mg}$ ) is established in the structure of dispensable amino acids. With a deficiency in nutrition of these amino acids in the human body, metabolic disorders can occur and, as a result, various diseases occur. [13].

It is known that the usefulness of proteins is determined not only by the content of amino acids, but also by their specific relationship, balance, easy digestibility, and good digestibility.

The calculation of protein AS allows the determination of the first limited acid and is necessary in the calculation of AAS and BV of protein. When calculating the AS, the sum of sulfur-con- 
taining and aromatic amino acids is taken into account, since methionine in the body is converted to cysteine, and phenylalanine is transformed into tyrosine (Table 2).

Table 1

Amino acid composition of broccoli cabbage protein of different varieties, $\mathrm{mg} / 100 \mathrm{mg}$ of protein

\begin{tabular}{|c|c|c|c|c|}
\hline Amino acids & Parthenon F1 hybrid & Monaco F1 hybrid & Belstar F1 hybrid & Quinta F1 hybrid \\
\hline \multicolumn{5}{|c|}{ indispensable amino acids, incl: } \\
\hline valine & 5.96 & 5.07 & 4.98 & 5.01 \\
\hline isoleucine & 5.03 & 4.67 & 5.11 & 4.61 \\
\hline leucine & 5.96 & 5.34 & 6.02 & 5.29 \\
\hline lysine & 6.43 & 6.17 & 6.53 & 6.08 \\
\hline methionine + cystine & 6.22 & 5.89 & 6.41 & 5.78 \\
\hline threonine & 4.13 & 4.01 & 4.63 & 3.99 \\
\hline phenylalanine + tyrosine & 6.86 & 6.34 & 7.02 & 6.22 \\
\hline tryptophan & 1.36 & 1.24 & 1.56 & 1.21 \\
\hline Total & 41.95 & 38.73 & 42.26 & 38.19 \\
\hline \multicolumn{5}{|c|}{ dispensable amino acids, incl: } \\
\hline glutamic acid & 17.42 & 16.27 & 18.43 & 18.31 \\
\hline arginine & 6.90 & 6.02 & 6.88 & 6.82 \\
\hline aspartic acid & 10.56 & 9.54 & 10.21 & 10.18 \\
\hline serine & 4.60 & 4.06 & 4.53 & 4.41 \\
\hline glycine & 4.82 & 4.32 & 4.92 & 4.83 \\
\hline alanine & 5.50 & 4.97 & 5.20 & 5.11 \\
\hline proline & 5.03 & 4.79 & 5.33 & 5.19 \\
\hline histidine & 2.30 & 2.17 & 2.41 & 2.23 \\
\hline Total & 57.13 & 52.14 & 57.91 & 57.08 \\
\hline
\end{tabular}

The calculated AS indicates that the broccoli cabbage protein is a valuable source of indispensable amino acids. The speed of the overwhelming number of amino acids is close to the "reference" protein, and the content of methionine, tryptophan and isoleucine significantly exceeds it and is in the range from $165.1 \%$ to $183.1 \%$; from 121.0 to $156.0 \%$ and from 115.3 to $127.8 \%$ respectively.

The calculations show that the highest biological value is the cabbage broccoli protein of the Quint F1 variety (64.2). This variety is the most balanced in its amino acid composition compared to other varieties. The other tested cabbage varieties have no significant differences in this indicator and are characterized by a rather high biological value of the protein - within $60.5 \ldots 63.2$.

In addition to the calculated AS, the biological value of the protein can also be determined from the total content of indispensable amino acids in $100 \mathrm{~g}$ of protein. If the amount of indispensable amino acids in $100 \mathrm{~g}$ of protein is not less than $40 \mathrm{~g}$ - this indicates its high biological value. The total content of indispensable amino acids correlates with the results of an early calculation and confirms the high biological value of the cabbage protein of the varieties Parthenon and Belstar F1. 
Table 2

Quality of cabbage broccoli protein of different varieties

\begin{tabular}{|c|c|c|c|c|c|c|c|c|c|}
\hline \multirow{2}{*}{$\begin{array}{l}\text { Indispensable } \\
\text { amino acids }\end{array}$} & \multirow{2}{*}{$\begin{array}{l}\text { The FAO/ } \\
\text { WHO scale, } \\
\text { mg/100mg }\end{array}$} & \multicolumn{2}{|c|}{ Parthenon F1 hybrid } & \multicolumn{2}{|c|}{ Monaco F1 hybrid } & \multicolumn{2}{|c|}{ Belstar F1 hybrid } & \multicolumn{2}{|c|}{ Quinta F1 hybrid } \\
\hline & & AS & $\triangle \mathbf{A A S}$ & AS & $\triangle \mathbf{A A S}$ & AS & $\triangle \mathbf{A A S}$ & AS & $\triangle \mathbf{A A S}$ \\
\hline valine & 5.0 & 119.2 & 33.8 & 101.4 & 25.1 & 99.6 & 13.6 & 100.2 & 24.6 \\
\hline isoleucine & 4.0 & 125.8 & 40.4 & 116.8 & 40.5 & 127.8 & 41.8 & 115.3 & 39.7 \\
\hline leucine & 7.0 & $85.4^{*}$ & 0 & $76.3^{*}$ & 0 & $86.0^{*}$ & 0 & $75.6^{*}$ & 0 \\
\hline lysine & 5.5 & 116.9 & 31.5 & 112.2 & 35.9 & 118.7 & 32.7 & 110.5 & 34,9 \\
\hline $\begin{array}{l}\text { methionine }+ \\
\text { cystine }\end{array}$ & 3.5 & 177.7 & 92.3 & 168.3 & 92.0 & 183.1 & 97.1 & 165.1 & 89,5 \\
\hline threonine & 4.0 & 103.3 & 17.9 & 100.3 & 24.0 & 115.6 & 29.6 & 99.6 & 24.0 \\
\hline $\begin{array}{c}\text { Phenylalanine }+ \\
\text { tyrosine }\end{array}$ & 6.0 & 114.3 & 28.9 & 105.7 & 29.0 & 117.0 & 31.0 & 103.7 & 28.1 \\
\hline tryptophan & 1.0 & 136.0 & 50.6 & 124.0 & 47.7 & 156.0 & 70.0 & 121.0 & 45.4 \\
\hline$\Sigma \Delta \mathrm{AAS}$ & & & 295.4 & & 294.2 & & 315.8 & & 286.2 \\
\hline AAS & & & 36.9 & & 36.8 & & 39.5 & & 35.8 \\
\hline BV & & & 63.1 & & 63.2 & & 60.5 & & 64.2 \\
\hline
\end{tabular}

Note: * the first limited acid; $\triangle A A S$ - the ambiguity coefficient of the amino acid score

The broccoli cabbage protein, despite its low content, plays an important role in its storage and processing. It is well known that due to hydrophilic properties, proteins are able to retain moisture, which affects the safety of consumer properties of both fresh cabbage and canned in various ways. Along with this, the use of various technological methods, including blanching, contributes to the partial hydrolysis of the protein with the formation of free amino acids, which subsequently decompose to ammonia, amides and hydrogen sulfide. When amino acids interact with sugars, dark-colored compounds form and indispensable amino acids (lysine, threonine) are lost. It is known that in addition to lysine and threonine, arginine, valine, histidine, methion, cysteine, which, as a result of the cleavage of these lysine and hydrogen sulfide, are unstable to high temperatures, hydrogen sulphide is released, which significantly affects the organoleptic properties of vegetables, namely the smell [13]. Relatively stable to high temperatures are proline, isoleucine, alanine and aspartic acid.

The above is evidence of the need for further research on the effect of various canning methods on the protein component of broccoli.

\section{Conclusions}

The amino acid composition of the protein of the investigated varieties of broccoli cabbage is represented by 8 indispensable and 8 dispensable amino acids. The highest content of amino acids is characteristic for cabbage varieties Parthenon and Belstar F1. The calculated amino acid scores show that the broccoli cabbage protein is a valuable source of isoleucine, methionine, phenylalanine and tryptophan. The performed calculations confirm the high biological value of the protein. The highest biological value is the protein of cabbage broccoli varieties Quinta F1. This variety was the most balanced in its amino acid composition compared to other varieties. The conducted researches allow to recommend varieties Parthenon and Belstar F1 as a source of high-grade vegetable protein.

The above results are only part of a comprehensive work. It is promising to conduct scientific research on the protein component of other varieties of broccoli and their changes during the storage of vegetables in various ways. 
The research results of the amino acid composition and biological value of the broccoli cabbage protein of varieties bred and grown in different countries will contribute to expanding the scientific database on the effect of climatic growing conditions on the biological value of the broccoli cabbage protein.

The obtained results can also be useful for specialists in the agricultural sector and the fruit and vegetable industry.

\section{References}

[1] Kudynov, P. Y., Shchekoldyna, T. V., Slyzkaia, A. S. (2012). Sovremennoe sostoianye y struktura myrovykh resursov rastytelnoho belka. Yzvestyia vuzov. Pyshchevaia tekhnolohyia, 5-6, 7-9.

[2] Guss, J. M., Freeman, H. C. (2006). Cucumber Basic Protein. Handbook of Metalloproteins. doi: 10.1002/0470028637.met188

[3] Fallis, A. G. (2013). Vegetables I - Asteraceae, Brassicaceae, Chenopodicaceae, and Cucurbitaceae. Journal of Chemical Information and Modeling, 89-97.

[4] Houška, M., Vinagre Marques da Silva, F. (Eds.) (2017). High Pressure Processing of Fruit and Vegetable Products. Boca Raton: CRC Press, 194. doi: 10.1201/9781315121123

[5] Mishra, D. K., Sinha, N. K. (2011). Principles of Vegetable Canning. Handbook of Vegetables and Vegetable Processing, 243-258. doi: 10.1002/9780470958346.ch11

[6] Florkowski, W. (2017). Integrated View of Fruit and Vegetable Quality. Boca Raton: CRC Press, 354. doi: 10.1201/9781351073769

[7] Bolotskykh, A. S. (2001). Ovoshchy Ukrainy. Kharkiv: Orbyta, 1088.

[8] Belinska, S. O. (2017). Eksportno-importnyi potentsial Ukrainy v torhivli zamorozhenymy ovochamy. Tovary i rynky, 2, 72-79.

[9] Favell, D. J. (1998). A comparison of the vitamin C content of fresh and frozen vegetables. Food Chemistry, 62 (1), 59-64. doi: 10.1016/s0308-8146(97)00165-9

[10] Derzhavnyi reiestr sortiv roslyn, prydatnykh dlia poshyrennia v Ukraini (2015). Derzhavna veterynarna ta fitosanitarna sluzhba Ukrainy. Available at: http://vet.gov.ua/node/919

[11] Lazarus, W. (1973). Purification of plant extracts for ion-exchange chromatography of free amino acids. Journal of Chromatography A, 87 (1), 169-178. doi: 10.1016/s0021-9673(01)91530-4

[12] Kozarenko, T. D. (1975). Yonoobmennaia khromatohrafyia amynokyslot. Novosybyrsk: Nauka, 136.

[13] Rohov, Y. A. (2008). Khymyia pyshchy. Printsypy formyrovaniya kachestva miasoproduktov. Sankt-Peterburg: Yzdatelstvo RAPP, 340. 